Revista Mídia e Cotidiano Artigo Seção Livre

Volume 13, Número 2, agosto de 2019

Submetido em: 07/05/2019

Aprovado em: 04/07/2019

\title{
\#Rocinha: A representação no Instagram da maior favela do Brasil
}

\section{\#Rocinha: The representation of Brazil's largest favela on Instagram}

\section{Resumo}

\author{
Paulo Henrique Soares ALMEIDA ${ }^{1}$
}

Celia MOTA ${ }^{2}$

A popularização das redes sociais atinge milhões de pessoas, causando um enorme impacto na maneira como elas consomem, interpretam e narram o mundo globalizado. É a partir desse cenário que analisamos a representação da Rocinha - maior favela do Brasil - no Instagram, durante o mês de dezembro de 2017. Nossa hipótese é que, por meio de novas tecnologias e formas de interatividade, a Rocinha ganha voz para mostrar que sua cultura e identidade vão muito além do estereótipo de pobreza, violência e do tráfico de drogas. Para o estudo, empregamos como metodologia a análise crítica da narrativa com ênfase na semiótica, tendo como base os estudos do professor Luiz Gonzaga Motta (2013).

Palavras-chave: Redes Sociais; Representação; Narrativa; Cultura.

\begin{abstract}
The popularisation of social networks reaches millions of people, making a significant impact on how people consume, interpret and narrate the globalised world. In this context, we analyse the representation of Rocinha - the largest favela in Brazil - on Instagram during the month of December in 2017. Our hypothesis is that the new technologies and forms of interactivity provide opportunities for Rocinha to echo its voice and show that their culture and identity go far beyond the stereotypes of poverty, violence, and drug trafficking. For this study, we adopted a methodological approach that draws from critical narrative analysis with an emphasis on semiotics, based on studies conducted by Professor Luiz Gonzaga Motta (2013).
\end{abstract}

Keywords: Social Networks; Representation; Narrative; Culture.

\footnotetext{
${ }^{1}$ Jornalista, Doutorando e Mestre em Comunicação pela Universidade de Brasília (UnB) e especialista em Leitura e Produção de Texto pela Universidade Católica de Brasília (UCB). Pertence aos grupos de pesquisa Jornalismo e Construção Narrativa da História do Presente e Cultura, Mídia e Política, da UnB. E-mail: pauloalmmeida@gmail.com.

${ }^{2}$ Doutora em Comunicação, pesquisadora associada ao Programa de Pós-graduação da Faculdade de Comunicação da Universidade de Brasília. Participa dos Grupos de Pesquisa: Jornalismo como Narrativa da História do Presente; e Cultura, Mídia e Política. É membro da Rede Nacional de Telejornalismo e da Rede Nacional de Narrativas, filiadas a SBPJOR. E-mail: cladmota@gmail.com.
} 


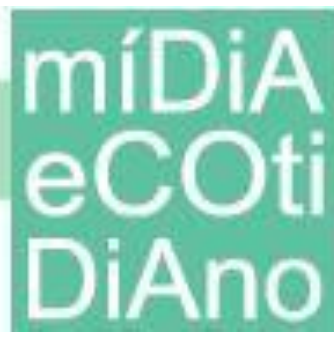

\section{Introdução}

As redes sociais fazem parte da vida de milhões de pessoas em todo o mundo e, no Brasil, não é diferente. Para Recuero (2012), é nessa conversação em rede que hoje nossa cultura está sendo interpretada, narrada e construída, sendo preciso um olhar atento para estes novos meios de comunicação. No entanto, embora a partir da segunda metade do século XX, pesquisadores dos mais diversos ramos - como Manuel Castells, Paul Baran e Pierre Lévy - desenvolveram explicações para entender as mídias digitais e suas relações com o cotidiano, o caminho de estudo não é simples. Pesquisar esses meios e seus efeitos é uma tarefa difícil de ser capturada e enquadrada em um único foco. "Por serem dinâmicas, essas práticas sociais mudam com o tempo e com as próprias ferramentas que surgem" (RECUERO, 2012, p. 18).

Ao refletir sobre as teorias das mídias digitais, Martino (2015) destaca alguns conceitos-chave, tais como: interatividade, ciberespaço, convergência, inteligência coletiva e cultura participatória. E, embora saibamos que essas interações na internet nem sempre se caracterizam pela democracia, pelo fortalecimento da cidadania e por discussões sobre temas de interesses públicos, a política na rede também se relaciona com diversas manifestações e afirmações de identidade, na disputa pela chance de chamar atenção para problemas sociais, procurando não apenas o engajamento, mas também a visibilidade. No processo, cada rede social tem sua própria dinâmica, pontos positivos e negativos, e isso está ligado, de alguma maneira, à sua própria arquitetura.

Entre as mídias digitais está o Instagram, aplicativo gratuito lançado em outubro de 2010, que permite ao usuário postar fotos e filmes. De acordo com Carolyn Everson, executiva do Facebook, em setembro de 2017, a rede social já alcançava 800 milhões de usuários ativos por mês, com 500 milhões acessando todos os dias (G1, 2017). O número de brasileiros no Instagram também é significativo. Segunda maior base de participantes nessa rede social, em outubro de 2017, o país já contava com 50 milhões de usuários ativos mensalmente, sendo um dos principais produtores de conteúdo na plataforma (FOLHA, 2017). Ou seja, mais de 75\% dos brasileiros conectados à internet usam o aplicativo.

Ter seguidores e postagens curtidas ou comentadas no Instagram é uma forma de ganhar reputação. Um capital simbólico que representa o sucesso midiático, onde o 


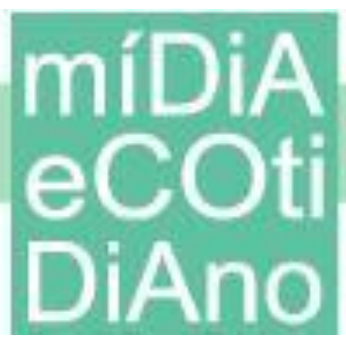

usuário só existe quando há a interação com o outro. "Estudo de tendência de consumo realizado pela Ford mostra que $62 \%$ dos adultos têm melhor autoestima depois de serem curtidos e/ou compartilhados em redes sociais" (BRESSANE, 2014). Entre as formas de terem as imagens visualizadas, o uso da hashtag (\#) no conteúdo é fundamental. O artifício funciona como uma maneira de catalogar os temas publicados, facilitando a interação e o sistema de busca no aplicativo.

Martino (2015) lembra que Castells (2010) define esse tipo de interação como “comunicação pessoal de massa". Segundo o autor, o Instagram, assim como as demais mídias digitais, herda da comunicação de massa a potencialidade de alcançar uma incontável quantidade de pessoas, ao mesmo tempo que se trata, em geral, de uma criação individual, direcionada a uma rede de público com interesses comuns. Nesse sentido, nas palavras de Castells, as três formas de comunicação - interpessoal, de massa e pessoal de massa - coexistem, interagem e complementam-se mutualmente no campo digital. "Esses emissores-receptores formam redes de comunicação nas quais as mensagens são discutidas, ressignificadas, reelaboradas e compartilhadas" (MARTINO, 2015, p. 106).

Nesse campo, os novos meios digitais nos proporcionam diferentes realidades e desafios. Entre eles, pensar as maneiras de diminuir as desigualdades de representações na comunicação, discutindo suas exclusões e inclusões de formas de ver o mundo. Como exemplo, enquanto alguns países estão presentes quase todos os dias no noticiário, outros raramente aparecem. Enquanto alguns povos são conhecidos pela sua criatividade, economia e turismo, outros tendem a ser representados pela imprensa somente a partir de pontos de vistas negativos, como agressivos, bélicos ou potencialmente perigosos para os outros. Sendo assim, é possível que, nas redes sociais, esses grupos ganhem um novo vínculo de produções de imagens e aparências? Esta é a pergunta chave que pretendemos discutir neste artigo.

Com base nessas informações, este trabalho não pretende esgotar o tema, mas refletir, em tempos de globalização e mundialização da cultura, de que forma grupos sociais ou locais, muitas vezes estigmatizados, estão sendo representados nessas redes por meio da comunicação pessoal de massa. Como objeto de estudo, escolhemos analisar a representação da Rocinha no Instagram. É possível dizer que essa rede social colabora para produções de discursos heterogêneos, voltados para a cultura, valores e mensagens 


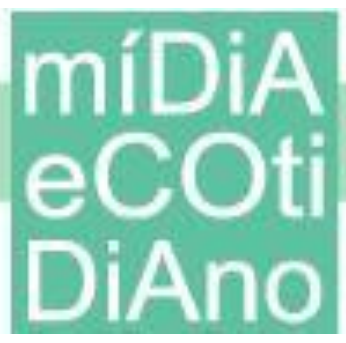

que fortalecem a cidadania em uma representação mais plural da comunidade? Nossa hipótese é que, por meio de novas tecnologias, como o Instagram, a Rocinha ganha voz para mostrar que sua cultura e identidade vão muito além do estereótipo de pobreza, violência e do tráfico de drogas.

\section{Identidade e cultura visual}

Em primeiro lugar, é preciso observar que fotografias não são apenas interpretações do real, e sim vestígios do real. São evidências documentais. Platão já chamava a atenção para o fato de que a visão humana era uma simples cópia da realidade. Em artigo anterior (MOTA, 2012), observou-se que uma imagem, simplesmente, não se transforma em cultura visual até que seja visualizada. Visualizar não é simplesmente produzir objetos visíveis, mas comprometer a vida cotidiana numa cultura de commodity que demanda o nosso olhar para gerar valor para alguém mais. "Com isso, a visualização se apropria do fazer histórico e se transforma na principal referência dos significados que vamos construindo sobre o mundo que vivemos" (MOTA, 2012, p. 199).

Carregada de valores simbólicos e de poder, a cultura visual está intensamente mediada e em todos os lugares: no cinema, nas telas da TV ou do computador, nos Ipads, nas inúmeras câmeras de segurança instaladas nas ruas das cidades, nos jogos digitais, no Facebook, em vídeos do YouTube e em uma infinidade de outros meios, inclusive em nosso objeto de estudo, que é o Instagram. As imagens produzidas e divulgadas nessas ferramentas são culturas visuais complexas porque, ao interpretar uma realidade específica ou acontecimento, incorporam discursos sociais e políticos que ajudam a constituir a visão de mundo do indivíduo, os pensamentos e as ações, além de formar identidades. Mirzoeff define esta mediatização como um trabalho, pois produz valores para os outros (MIRZOEFF, 2010).

É a partir dessa visualização que a memória social de um país ou de uma comunidade vai se construindo. A imagem opera como um acordo de olhares. São lembranças que podem ser reconhecidas e reconstruídas. "O que vai para o fundo da memória coletiva é o resultado de um conflito de significados em busca de hegemonia. $\mathrm{O}$ que se retém na memória é aquilo que ainda está vivo na lembrança de uma comunidade" (HALBWACHS, 1990, p.96). 
Problematizar as representações que o Instagram constrói sobre os moradores da Rocinha significa, portanto, buscar as referências de identidades daquela comunidade. Para compreender essas referências, usamos, em princípio, o conceito de cultura tal como proposto por Raymond Williams. Um dos fundadores dos estudos culturais, Williams (2011) explica que, embora o termo "cultura" tenha recebido diferentes definições - ideia de cultivar alguma coisa, conhecimento erudito, desenvolvimento e progressos sociais ao longo dos anos, hoje ele se explica por meio de uma definição antropológica. Cultura liga-se à noção de experiência, ou seja, às práticas e atividades relacionais vividas em sociedade. Isso leva a cultura a ser interpretada como um sistema de significações amplo, que inclui não apenas as artes e as produções intelectuais, mas sim todas as práticas significativas, como as narrativas, o jornalismo, a moda, a publicidade, entre outros. $\mathrm{Na}$ obra Culture and Society, Williams analisa o conceito de cultura como uma prática popular que se aproxima do conceito de 'habitus' expresso por Pierre Bourdieu (1977). Ou seja, a cultura como uma rede de significados e atividades compartilhados de toda uma comunidade.

Este avanço em consciência de que fala Williams leva ao surgimento de culturas ligadas a processos de identidade que se antepõem à cultura de massa. A cultura é, assim, aquilo para o que vivemos. "Afeto, relacionamento, memória, lugar, comunidade, um sentido de significado último: tudo isso está mais próximo, para a maioria de nós, do que cartas de direitos humanos ou tratados de comércio", afirma Eagleton (2005). É também o significado adotado por Hall, para quem "cultura is about 'shared meanings". Em termos simples, diz respeito a "significados compartilhados", tendo a linguagem o papel fundamental por meio do processo de representação (HALL, 2009 , p. 2). Representação, segundo o autor, significa usar a linguagem para dizer alguma coisa com sentido sobre algo ou alguém a partir de símbolos, seja por palavras, músicas, imagens, fotos, entre outros. Em resumo, a representação conecta significado e linguagem com a cultura no processo de produção, consumo e construção de identidade (HALL, 2009). "Dizer que duas pessoas pertencem à mesma cultura é dizer que eles interpretam o mundo e se expressam, aproximadamente, da mesma maneira" (HALL, 2009, p. 2). Essa relação está associada ao que Hall destaca como circuito cultural, onde as práticas 


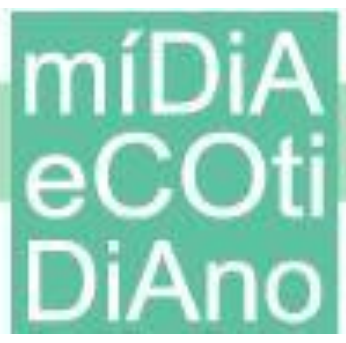

de "produção, circulação, consumo, reprodução e identidade" estão conectadas entre si, em círculo, mas são independentes.

Nesse circuito, a forma como recebemos informações sobre determinado tema ou área de atividade social e a maneira como interpretamos essa mensagem está diretamente relacionada com os discursos dos meios, que produzem sentido e significados que serão decodificados e reproduzidos no campo social. É o que Hall enfatiza como quadros de referência ou mapas culturais. "Nós damos às coisas significados pelo modo como as representamos, as palavras que usamos, histórias que contamos, emoções que a elas associamos e imagens que produzimos" (HALL, 2009, p 3). Na concepção de Hall, a maneira como interpretamos essas práticas culturais e discursos vão construir nossa visão de mundo e identidade. A ideia é a mesma elucidada por Kathryn Woodward (2012). Para a autora, a construção da identidade é tanto simbólica quanto social e está ligada a inclusão e exclusão, podendo ser fluida, mas, em todo caso, marcada simbolicamente por meio de representações.

Temos então que a cultura da mídia fornece material importante com o qual muitas pessoas constroem seu senso de classe, etnia, raça, nacionalidade, sexualidade e da relação entre nós e eles. Ecoando Hall e Woodward, Kellner (2001) também vai afirmar que essa cultura midiática ajuda a modelar a visão prevalecente de mundo e os valores mais profundos, definindo o que é considerado bom ou mau, positivo ou negativo, moral e imoral. "As narrativas veiculadas pelas mídias fornecem os símbolos, os mitos e os recursos que ajudam a constituir uma cultura comum para a maioria dos indivíduos" (KELLNER, 2001, p. 9).

Nesse processo, a imagem também tem um papel importante como referência e índice de um significado dominante, que vai contribuir para o que chamamos de cultura visual, uma prática de olhar o mundo mediado que nos cerca, compartilhando sentidos e narrativas sobre nós mesmos.

\section{O sentido de favela no Brasil}

Segundo o dicionário Houaiss, favela significa "conjunto de moradias precárias, situados geralmente em morros, onde vive a população de baixa renda dos centros urbanos" (HOUAISS, 2015). A origem da palavra guarda referência com a Guerra 


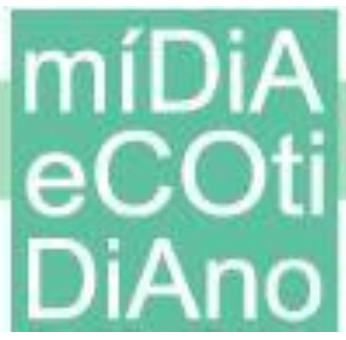

de Canudos, confronto entre um movimento popular de fundo sociorreligioso e o Exército da República, que durou de 1896 a 1897, no interior do estado da Bahia, no Brasil. O povoado de Canudos, que desafiou o governo federal, foi construído perto de um local com arbustos chamado favela, nome de uma planta bastante comum na região, a Cnidoscolus quercifolius.

Após a guerra, os que voltaram à cidade do Rio de Janeiro deixaram de receber ajuda do governo e, como não tinham onde morar, construíram rústicas habitações no morro da zona portuária do Rio. Conhecido como Morro da Providência, o local recebeu então o nome Morro da Favela, em referência às lembranças de Canudos. A partir da década de 20 do século passado, as habitações de barracos que se erguiam sobre os morros do Rio de Janeiro passaram a ser designadas pelo mesmo nome.

$\mathrm{O}$ começo das favelas cariocas também está relacionado à crise habitacional após a Guerra do Paraguai (1864-1870); a proliferação de cortiços, que foram derrubados com as inúmeras campanhas de higienização urbana do Rio de Janeiro; e ao fim da escravidão no século XIX, quando parte dos escravos libertos se deslocou para a capital federal com o propósito de se fixar informalmente em lugares sem infraestrutura.

Pesquisadores sobre o tema, Renato Meirelles e Celso Athayde, autores do livro Um País Chamado Favela, explicam que, em muitas ocasiões, no discurso oficial, favela foi sinônimo de problema que o poder público deveria antes remover que resolver. "A palavra esteve associada à precariedade de condições higiênicas e sanitárias. Reduziase a metáfora alusiva à insalubridade, que indicava foco de doenças contagiosas" (MEIRELLES; ATHAYDE, 2014, p. 8). Foi percebida como um espaço que depreciava o valor imobiliário de bairros prósperos da cidade. Em seguida, como apontam os autores, tornou-se fonte do mal, sede do perigo, da ameaça aos bons costumes, que demandavam campanhas sanitárias e moralizadoras. Símbolo do tráfico de drogas, roubos e violência que assombram a cidade dividida entre o bem (o povo do asfalto) e o mal (os que moram no morro). "Desde os anos 1980, virou sinônimo de transgressão à lei e à ordem, espaço que requer incursões policiais, praça de guerra" (MEIRELLES; ATHAYDE, 2014, p. 9).

Reportagem publicada no site G1 em $1^{\circ}$ de fevereiro de 2018 mostra, por exemplo, que de acordo com o aplicativo Onde Tem Tiroteio (OTT), em janeiro de 2018, houve mais de 500 tiroteios no Rio de Janeiro. Entre as nove áreas de favelas que mais 


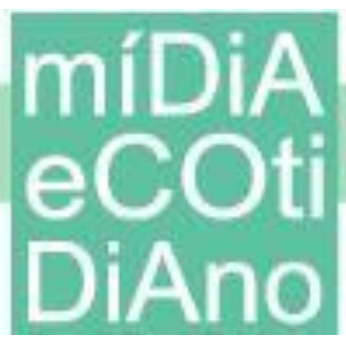

registraram conflitos, quatro possuem Unidades de Polícia Pacificadora (UPPs): Cidade de Deus (41 tiroteios), Rocinha (32 tiroteios), Jacarezinho (23 tiroteios) e Vila Kennedy (13 tiroteios). Nessas regiões, foram 109 tiroteios em 30 dias, o que dá uma média de mais de três casos por dia. "Em cada comunidade, os conflitos são protagonizados por disputas entre traficantes ou em confrontos com policiais. Todos assustando moradores e até interrompendo o trânsito, como na Cidade de Deus" (G1, 2018).

Na contramão de notícias como essa, Meirelles e Athayde (2014) criaram, em 2013, o Data Favela, primeiro instituto de pesquisa e estratégias de negócios que estuda o comportamento e o consumo dos moradores dessas comunidades. Uma pesquisa inédita, com 63 comunidades brasileiras, feita pelo instituto, mostra, por exemplo, que em 2013, a média salarial do favelado era de 1.068 reais contra 603 reais em 2003, tendo um aumento de 54,7\%. No cenário do Brasil geral, o crescimento foi de apenas 37,9\%, quando a média salarial passou de 1.172 reais para 1.616 reais. Além disso, de acordo com o Data Favela, $81 \%$ dos moradores gostam da comunidade em que estão fixados e 66\% não estão dispostos a abandoná-la. De acordo com Meirelles e Athayde (2014), a favela, apesar de seus dramas e suas deficiências, "é hoje o lugar dos emergentes, dos que costuram esperanças, onde são gerados 63 bilhões de reais, valor que corresponde ao PIB de países como Bolívia e Paraguai” (MEIRELLES; ATHAYDE, 2014, p. 26).

Estudo mais recente, divulgado em oito de setembro de 2017 pelo instituto, mostra também que $52 \%$ das pessoas que vivem nessas comunidades têm vontade de empreender, mais de $80 \%$ tem acesso à internet e $99 \%$ destes estão no Facebook. "Dos 11,7 milhões de brasileiros que vivem nas comunidades, cerca de $20 \%$ sustentam-se do que apuram em pequenos negócios” (MEIRELLES; ATHAYDE, 2014, p. 77). Em 2013, $65 \%$ eram da classe $\mathrm{C}$ e $16 \%$ já tinham viajado de avião. Entre os jovens de 18 a 30 anos, $73 \%$ já haviam estudado mais que os pais, de acordo com o Data Favela.

O fim da violência, com $51 \%$, não é o principal anseio do morador de favela do Brasil. Perde, por exemplo, para quem almeja melhor qualificação profissional, 61\%, ou mesmo serviço público de qualidade nas comunidades, 58\%. "O povo das comunidades tem procurado reescrever a palavra favela, dando a ela um valor positivo. No entanto, o que fez e faz falta é pensar os territórios populares como partes indissociáveis da trama urbana" (MEIRELLES; ATHAYDE, 2014, p. 11). 


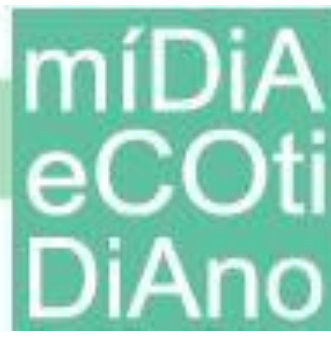

\section{\#Rocinha}

De acordo com o Censo 2010, divulgado pelo IBGE, o Rio de Janeiro é a cidade brasileira com maior população vivendo em aglomerados subnormais. São 1.393.314 pessoas nas 763 favelas da cidade, ou seja, 22,03\% dos 6.323 .037 moradores do Rio de Janeiro. Os números refletem a falência das políticas habitacionais, que estão longe de atender à demanda por moradias na cidade. Se comparados com os números do Censo 2000 do IBGE (quando havia 1.092.283 moradores de favelas no Rio, ou 18,65\% dos habitantes do município), o crescimento da população em aglomerados subnormais em 10 anos foi de 27,65\%, enquanto a cidade regular, excetuando os moradores das favelas, cresceu a um ritmo oito vezes menor, apenas 3,4\%, passando de 4.765 .621 para 4.929.723 nesses dez anos.

Localizada na Zona Sul do município do Rio de Janeiro, entre os bairros da Gávea e São Conrado (dois dos bairros com o imposto sobre a propriedade predial e territorial urbana - IPTU - mais alto da cidade), a Rocinha se destaca por ser a maior favela do país, com mais de 100.000 moradores.

A comunidade, que funciona 24 horas, tem características peculiares. Pacificada em 2011, a Rocinha carrega o status de símbolo do tráfico da zona sul, sendo ainda palco de muitos conflitos. Para se ter uma ideia de como a violência é significante na representação da comunidade, quando, em fevereiro de 2018, buscamos no Google a expressão "favela da Rocinha”, apareceram 538.000 citações. Quando mudamos a frase no campo de busca para "guerra favela da rocinha", apareceram mais de 206.000 referências em apenas 30 segundos. No site do jornal Folha de S. Paulo, um dos principais veículos de comunicação do Brasil, a expressão "favela da Rocinha" registrou 2.684 resultados, sendo que, na primeira página, todas as referências eram à guerra do tráfico, tiroteios, mortes e bandidos. Manchetes como "Polícia e criminosos trocam tiros na favela da Rocinha”, já se encontram na editoria de Cotidiano.

A violência e o tráfico de drogas são problemas que existem há anos na Rocinha. De acordo com reportagem de Paula Bianchi (2018), publicada no site de notícias UOL em fevereiro de 2018, desde setembro de 2017, a favela vivia alguns dos momentos mais violentos da sua história. Cerca de 60 homens ligados ao traficante Antônio Francisco Bonfim Lopes, o Nem (que durante a pesquisa estava preso num 


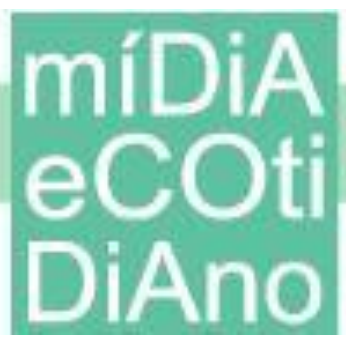

presídio federal em Porto Velho), invadiram a comunidade para expulsar Rogério Avelino da Silva, o Rogério 157, seu antigo aliado. Desde então, a disputa pelo poder da favela tornou tiroteios e incursões policiais situações rotineiras. Até 6 de fevereiro de 2018, "ao menos 39 pessoas apontadas pela polícia como suspeitas morreram em confrontos com a PM. Uma média de duas mortes por semana, além de um policial militar e de uma turista espanhola que visitava a região" (BIANCHI, 2018).

Os contrastes são muitos, em uma favela em constante movimento. $\mathrm{Na}$ Rocinha, becos, vielas e pequenas praças formam um tecido denso da sociabilidade, religiosidade e humanidade, mostrando que sua identidade é também plural. Se em áreas como a Vila Macega encontram-se casas de madeira em situação de risco e sem infraestrutura, em bairros como o Barcelos, é possível visualizar uma grande variedade de comércio e serviços, além de muitos imóveis residenciais de melhor qualidade. "A Rocinha é dividida em duas partes. Quem mora mais embaixo paga água, luz e internet; quem fica mais em cima, não. Quanto mais alto, o custo de vida é mais barato", conta Roberta Martins, nome fictício de uma moradora da comunidade, que concordou em ser entrevistada para esta pesquisa, desde que sua identidade fosse mantida em sigilo.

Ela aceitou conversar sobre seu dia a dia na Rocinha, mas logo disse que não falaria sobre o tráfico e a violência, e que, apesar desses aspectos, não quer sair de lá. Disse estar acostumada com a comunidade onde nasceu e tem laços afetivos. Mora em uma casa alugada por R\$ 400 com a família, incluindo uma filha, o marido e a cunhada. "Meu sonho é ter minha casa própria na Rocinha”, conta Roberta, que sofre o preconceito de morar em um local simbolizado pelo crime. "A mídia retrata apenas a violência, mas lá também tem gente do bem, que não tem culpa dessa realidade. Muitas pessoas aqui embaixo, na cidade, ficam com medo quando eu falo que vivo na Rocinha, mas lá é o lugar onde eu moro. Temos regras a serem respeitadas. Apesar de tudo, nos divertimos também. Vamos aos bailes, forró, tem livraria... só não tem cinema. Há escolas de inglês gratuitas, muitas casas com TV a cabo e ar condicionado. Muitas pessoas ganham em média dois mil reais", disse a entrevistada, sentada a uma mesa no Fashion Mall, shopping de luxo, localizado no bairro de São Conrado, a menos de 500 metros da comunidade.

Um médico psiquiatra, que atende na Rocinha, conta que, apesar de a imprensa focar na criminalidade, $70 \%$ do que a mídia representa sobre a comunidade é 


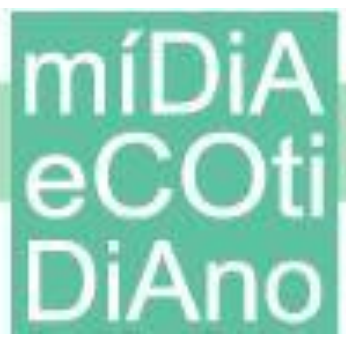

real. "Mudou muito nos últimos meses, com a disputa de facções pelo poder no morro. Antes, no começo da pacificação, era melhor. Hoje, a violência está cada vez mais constante. No entanto, ao mesmo tempo em que a população local não se sente segura de comentar o assunto, é fato que ela também já está acostumada com esta realidade e vive do que tudo isso proporciona. Lá, a violência é cultural. Quando tem tiroteios, nos alojamos em lugares em que há menos probabilidade de a bala chegar”, relata o médico, que atende na Rocinha 20 horas por semana. Entre os casos, a maioria com transtorno bipolar, esquizofrenia e depressão com causas multifatoriais, que envolvem vulnerabilidade, drogas, abusos sexuais e vida social precária. "Mas a alegria da população que consegue, apesar da dura realidade, sorrir e viver bem em meio ao caos, me deixa encantado e me ensina a valorizar a vida", afirma o médico.

\section{Metodologia: análise crítica da narrativa fotográfica}

Para o historiador inglês Peter Burke (2017), as imagens não são nem um reflexo da realidade social, nem um sistema de signos sem relação com a realidade social. "Elas são testemunhas do estereótipo, mas também das mudanças graduais, pelas quais indivíduos ou grupos veem o mundo social, incluindo o mundo de sua imaginação" (BURKE, 2017, p. 275). Ao estudar iconografia, Miani (2014) ressalta que, até bem pouco tempo, a pesquisa histórica relegou as imagens, bem como as obras de arte de uma maneira geral, a uma condição secundária na hierarquia das fontes históricas. Segundo o autor, superada a questão sobre a validade de fontes visuais, o problema agora é quanto ao dimensionamento valorativo atribuído a tais produções sociais.

A iconografia ainda padece pela falta de 'confiabilidade' por parte de alguns historiadores que se revelam conservadores quando se trata do reconhecimento da imagem como fonte privilegiada para o estudo de determinados objetos e/ou temas históricos (MIANI, 2014, p. 135).

Estar diante da imagem é estar diante do tempo, da memória, do registro, da forma única que cada sujeito consciente é capaz de ver o mundo. Nesse sentido, as imagens podem ser tanto evidência da história como a própria história, visto que a produção delas envolve, muitas vezes, um comportamento próprio dentro de uma ampla escala social, oferecendo acesso a aspectos do passado que outras fontes não alcançam. Ao representar e 


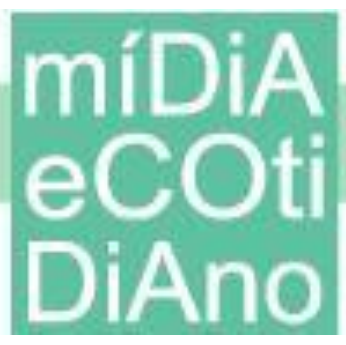

simular o ser, elas tendem a disseminar de forma plural o meio pensativo que a evoca. Elas oferecem evidências particularmente valiosas de práticas políticas, econômicas e sociais, como costumes, moda, arquitetura, gastronomia e cultura de uma maneira geral.

Para estudarmos essas práticas, percorremos a análise crítica da narrativa tal como proposta pelo professor Luiz Gonzaga Motta (2013). Segundo o autor, a Narratologia remete à cultura da sociedade e não apenas às suas expressões ficcionais. Ela passa a lidar com a construção dos significados e "pode ser utilizada como um procedimento analítico para compreender os mitos, as fábulas, os valores subjetivos, as ideologias, a cultura inteira de uma sociedade, seus valores canônicos e desvios" (MOTTA, 2013, p. 80). Dessa forma, utilizar o método na análise da fotografia nos ajuda a compreender a história contada e os sentidos produzidos por meio dos signos e símbolos que aparecem nessas narrativas visuais, observando os personagens, o valor simbólico dos elementos que aparecem na cena, a representação, os detalhes, o enredo, as entrelinhas da mensagem e a metanarrativa, sem deixar de lado o problema da polissemia. "Todo discurso é um poder que se exerce na relação entre quem fala e escuta. A análise sistemática da narrativa pode revelar esse jogo de poder e descortinar correlações de forças que se exerce nas relações discursivas interpessoais e coletivas" (MOTTA, 2013, p. 19).

Ao utilizarmos os estudos de Motta (2013), trabalhamos com a interpretação dos sistemas de signos imersos na cultura, seu contexto social, valores e efeitos de sentido com foco no fenômeno da significação, reconhecendo qual mensagem o narrador constrói e como ela será compreendida e reverberada. O caminho, portanto, se baseia na linguagem e é ela que intermediará toda a experiência hermenêutica enquanto experiência de mundo, servindo de meio, já que "toda interpretação se faz no seio da linguagem e nossa compreensão de mundo é, sempre, linguisticamente interpretada" (MOTA, 2017, p. 90).

Uma das dificuldades deste estudo envolveu a problemática da constituição e seleção do corpus. Como determinar uma coleção do material noticioso em tempo real produzida nas redes sociais? Como selecionar um bom material capaz de caracterizar o todo? Ao estudar Narratologia, Motta (2013) fala sobre uma seleção de corpus que conta com começo, meio e fim. Ecoando o autor, Bauer e Gaskell (2002) explicam que, em sistemas abertos, o delineamento de corpus são organizados a partir do que parecem fundamentos intuitivos. A fim de remediar o problema, os dois autores sugerem o 


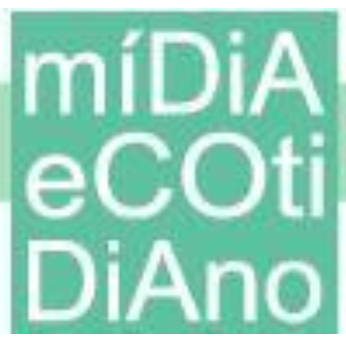

delineamento por meio de um processo cíclico, com a construção de um material com um enfoque particular.

Dessa forma, primeiro recortamos o período, $1^{\circ}$ de dezembro de 2017 a 16 de dezembro de 2017. A escolha da data se justifica pela importância. É quando acontece a prisão do traficante Rogério 157, que comandava o crime na região, sendo uma oportunidade para alcançarmos o objetivo principal deste estudo, que é mostrar que tipo de imagem surge na rede social quando a imprensa noticiava mais um conflito. Depois, percorremos quatro eixos interpretativos que chamam atenção na pesquisa de 2013 do instituto Data Favela, realizada por Meirelles e Athayde (2014): situação urbanística da Rocinha, infância, educação e cultura na comunidade.

As ferramentas para coleta de dados constituem na captação de imagens do Instagram (fonte principal) e entrevistas (fonte secundária) para melhor compreensão do contexto e mergulho hermenêutico. "O objetivo da entrevista é fornecer dados básicos para a compreensão dos atores sociais (suas crenças, atitudes, valores e motivações) e sua situação em contextos sociais específicos" (ADGHIRNI; MORAES, 2010, p. 244). Para isso, foram selecionados dois atores envolvidos com a Rocinha, uma moradora e um médico que trabalha na comunidade, com o intento de obter informações contextuais para ajudar a explicar os dados observados.

Outra dificuldade foi separar os autores das imagens. A princípio, a ideia seria recortar apenas as fotos postadas por moradores da Rocinha. No entanto, como esta seleção poderia gerar uma margem de erro significativa, já que nem sempre temos essa informação clara no Instagram, optamos por observar todas as fotos publicadas durante o recorte, confrontando os diferentes olhares dos produtores dessas imagens.

\section{Análise dos dados}

Utilizando o caminho metodológico apresentado, partimos para a análise das fotografias postadas no Instagram com a hashtag \#Rocinha, entre os dias 1 de dezembro de 2017 e 16 de dezembro de 2017. A pesquisa foi feita em duas partes. Na primeira, foi realizada uma coleta de dados gerais, um recorte quantitativo da análise de todas as 630 fotos que foram postadas durante o período com a hashtag \#Rocinha. Depois, a partir de uma imagem que tem a comunidade como foco principal, utilizamos os resultados obtidos 
no estudo para aplicação do método da análise crítica da narrativa fotográfica, desenrolando o fio da história. Para preservar as identidades dos usuários, optamos por identificar as fotografias destacadas em 1, 2, 3 e 4.

Seguindo a metodologia proposta por Motta (2013), analisamos nas imagens o plano de expressão, a linguagem e o modo como o narrador dá a conhecer ao leitor a realidade que ele quer evocar; o plano da história, onde observamos o conteúdo, o enredo e a intriga da narrativa, a caracterização dos personagens e o cenário; e o plano da metanarrativa, que nesse caso é o tema de fundo da narrativa visual e faz referência diretamente à identidade, mitos e imaginários culturais.

\section{Figura 1 - A arquitetura da desigualdade do Brasil}

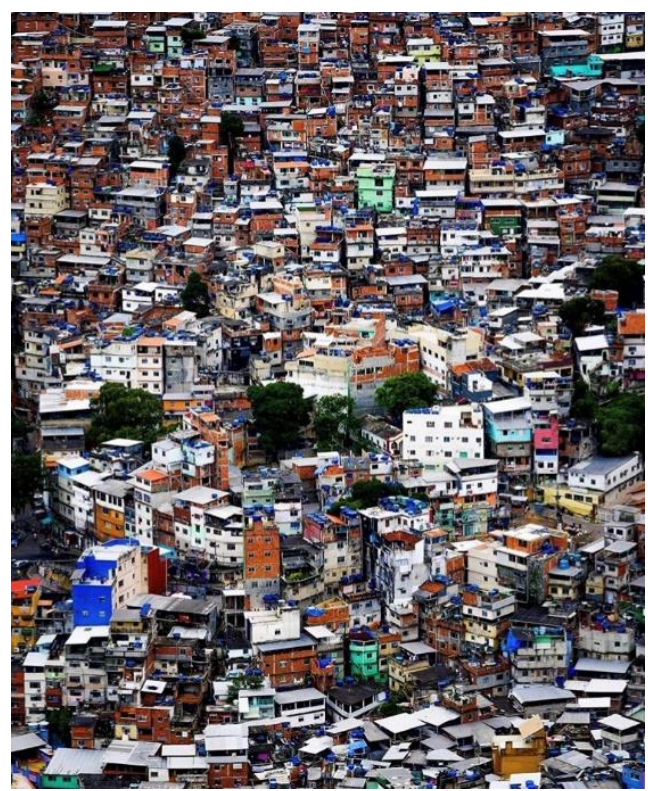

Fonte: Instagram.

Postada no Instagram no dia 9 de dezembro de 2017, por um estrangeiro de Singapura, a imagem 1 está entre as 173 fotografias (27,5\%) - do total de 630, que mostram a comunidade como protagonista. Desde a geotag e a legenda "Favela da Rocinha - a maior do mundo", (a maior do mundo, na verdade, é a comunidade de Kibera, no Quênia, com cerca de 2,5 milhões de habitantes), a fotografia chama atenção para o símbolo de imenso aglomerado urbano, o qual, de longe, já mostra uma terra onde a fiscalização e as leis não existem, a começar pela urbanização. É a imagem da arquitetura 


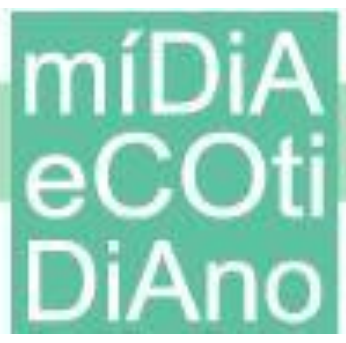

da desigualdade do Brasil, que se manifesta de três formas principais: na rede de serviços sociais, na estrutura política e nos espaços físicos.

Nesse sentido, o impacto do post nos leva a refletir e questionar sobre as condições do lugar e seus habitantes. Colocando a arquitetura em primeiro plano, ela mostra o morro, tendo como representação simbólica a dificuldade de subir, em suas variadas formas, tanto econômica, como social. A expressão "difícil acesso", causada pela falta de acompanhamento político desde sempre, é vista na foto a olho nu, sem precisar de lupa. O difícil acesso às residências do morro da Rocinha é também a falta de acesso à segurança, à educação e à saúde. A falta de ventilação e a situação precária de locais na comunidade, como o "beco dos malucos", por exemplo, contribui para que a Rocinha seja um dos principais focos de tuberculose do Brasil.

Basicamente sem áreas verdes, as casas e os comércios entrelaçados na fotografia mostram a integração das pessoas com a cidade, onde o público e o privado se misturam. Em um vídeo publicado no YouTube, o arquiteto Marat Troina faz um passeio de moto pela Rocinha e descreve a sua experiência. "Assumindo que a favela tem mais de $90 \%$ de becos e escadas. Qual seria a lei para essas construções?”, pergunta Marat. De acordo com o arquiteto, não existem leis urbanísticas adequadas à realidade da favela e o primeiro passo é aceitar a realidade. Para ele, criar leis viáveis, como uma atenção maior aos becos, evitando que estes sejam tampados, poderia ser uma saída para evitar problemas de saúde causados pela larga expansão da população.

Além da omissão do Estado, a falta de acesso que visualizamos na imagem também representa a carência de empresas públicas e privadas prestadoras de serviços. Companhias como as de telefones, luz e bancos, por exemplo, muitas vezes, justificam a falta de atendimento por se tratar de uma zona de risco, obrigando os moradores a buscarem soluções clandestinas para que não falte o básico em suas casas, como água e luz. As inúmeras caixas d'água que visualizamos, por exemplo, são recursos muitas vezes destruídos com os tiroteios.

No entanto, na figura 1 também é possível ver pontos coloridos, que, metaforicamente, podem ser interpretados como o lado positivo da comunidade. Faz referência a humanização da Rocinha, mostrando que o contraste não existe apenas entre o asfalto e o morro, mas também dentro da própria favela. A observação é confirmada 


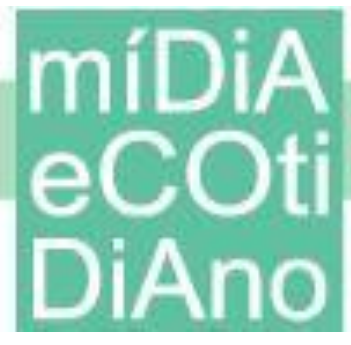

com a análise de todas as imagens do recorte deste estudo. Assim, observando as fotos postadas com a hashtag \#Rocinha entre 1 de dezembro de 2017 e 16 de dezembro de 2017 temos: 61 Crianças (aparentemente menores de 12 anos); 518 adultos, sendo que 293 podem ser identificadas como negros (57\%) e 225 como brancos (43\%); 311 homens (60\%) e 207 mulheres (40\%).

Se no livro de Meirelles e Athayde (2014), $42 \%$ das pessoas da comunidade acreditam que a melhoria de vida no morro acontece por conta do próprio esforço de cada um e não por conta das políticas públicas, as imagens do Instagram confirmam o dado. São cenas de pessoas trabalhadoras, que vivem a vida com a expressão de tranquilidade e boa conversa.

Nesta pesquisa, 124 fotos (20\%) são de propaganda de serviços e empresas na Rocinha. Entre elas, produtos alimentícios como paçoca, restaurante japonês, chinês, bares, lojas de roupas, calçados, carros, manicure, barbearia, tatuagem, centro odontológico e um grupo de mulheres que fazem da arte uma geração de renda (Figura 2). O número é exato aos dados do Data Favela de 2013, quando mostram que, "dos 11,7 milhões de brasileiros que vivem nas comunidades, cerca de $20 \%$ sustentam-se do que apuram em pequenos negócios" (MEIRELLES E ATHAYDE, 2014, p. 77).

Motta (2013) afirma que, definidos o frame dramático e seus conflitos, outra categoria da narrativa brota naturalmente: a personagem ou personagens que realizam os enfrentamentos. "Personagem é quem protagoniza ação, gera conflitos, conduz a intriga, personifica as contraditórias dualidades herói e vilão, marido e mulher, rico e pobre etc." (MOTTA, 2013, p. 175). É uma construção estratégica do narrador para provocar certas impressões, sentimentos, identificações ou rejeições no receptor. Dessa forma, observar atentamente as personagens presentes na história é compreender em torno do qual gira a intriga. Os significados que o autor pretende repassar argumentativamente aos seus interlocutores estão, muitas vezes, ancorados na representação das pessoas em cena, roupas, gestos, caracterização etc. Portanto, seguindo as orientações de Motta, o próximo passo é compreender a maneira como as pessoas foram retratadas em nosso recorte de pesquisa.

63 imagens (10\%) são representações de família, amigos, namorados ou grupos em harmonia. Foram retratados abraços, celebrações, encontros, confraternizações 


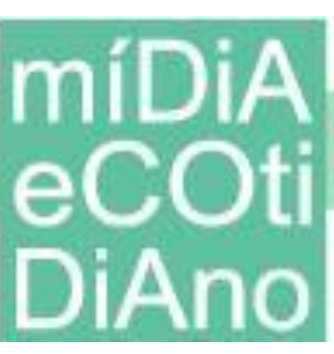

e exemplos de solidariedade, com moradores subindo o morro com doações de alimentos nas costas. Contrariando o estereótipo de pessoas malvestidas e descalças, não há rigorosamente nada que confirme a ideia. Assim como as mulheres que exibem o novo corte de cabelo, o bronzeado e as unhas pintadas, os homens também estão preocupados com a beleza e mostram seus corpos sarados.

Figura 2 - Mulheres em harmonia

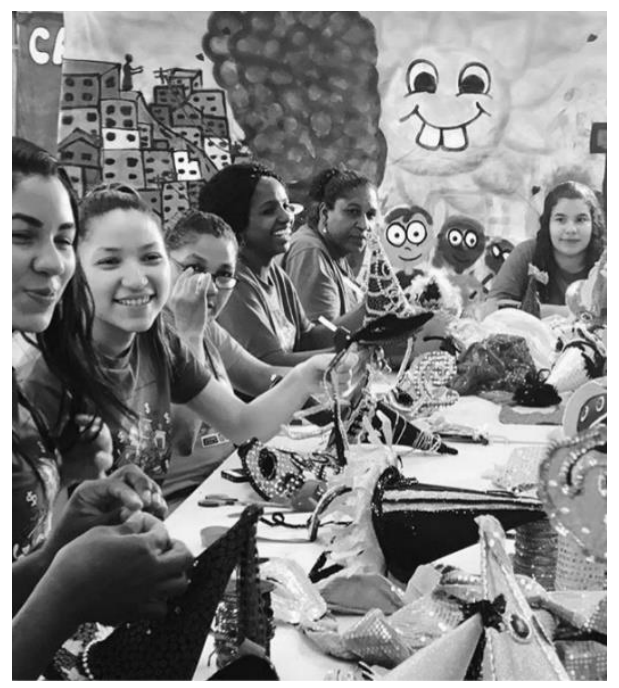

Fonte: Instagram.

Figura 3 - Curiosidade infantil

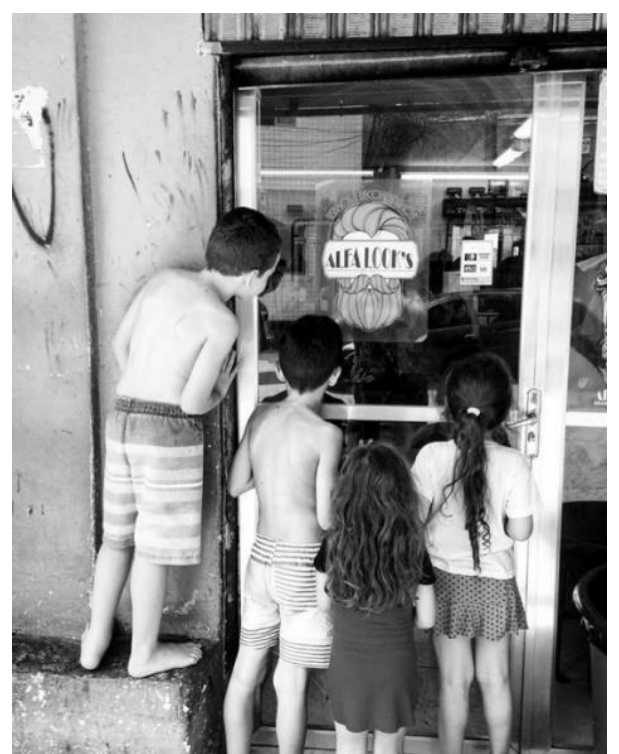

Fonte: Instagram. 


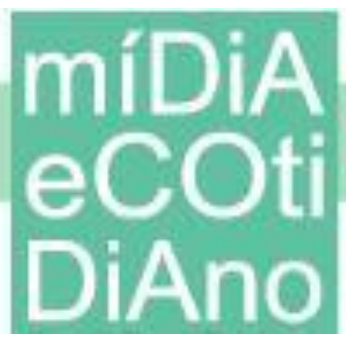

Muitas fotos do recorte foram tiradas por turistas que visitaram a comunidade e registraram a experiência pelo seu olhar. A imagem de um garoto brincando com uma bicicleta rosa, visivelmente pequena para o seu tamanho, e um grupo de crianças espiando o vidro de uma barbearia (foto 3 ) estão entre as fotografias que simbolizam a liberdade e a infância inocente. Feita por uma fotógrafa carioca que visitava o morro, a imagem 3 recebeu a legenda "curiosidade infantil".

Uma turista francesa postou a foto de três meninas negras, de tranças sorrindo para a câmera, com a legenda: "as princesinhas da Rocinha", recebendo 314 curtidas até o dia 6 de fevereiro de 2018. “Que futuro essas crianças terão?” Poderia ser a pergunta da fotógrafa, que registrou outras cenas do cotidiano da comunidade e postou em seu Instagram. Essas visitas, normalmente, são realizadas por empresas com guias locais, que oferecem o passeio à Rocinha como programa cultural e cobram, em média, 60 dólares. No Instagram ou na internet, diversos sites oferecem o "Favela Tour", como uma forma de conhecer melhor a história da maior favela brasileira e o cotidiano dos seus moradores. Um texto publicado no site The Guardian em 2 de novembro de 2013, com o título Favela Tourism in Rio de Janeiro, mostra por exemplo, como estas visitas são oferecidas como uma experiência de vida, um reality show, onde a desigualdade social brasileira é a principal atração turística.

Estratégias de produção de efeitos de real é também o que Motta (2013) aponta como um dos principais recursos do narrador para fazer com que o público interprete os fatos narrados como verdades. Nas imagens selecionadas, esse efeito de real está presente, por exemplo, nas figuras de linguagem e na fixação do tempo. No recorte desta pesquisa, 39 imagens $(6,1 \%)$ são de eventos culturais, incluindo festas com apresentações de cantores conhecidos nacionalmente como Xande, DJ, bailes, feijoada e propaganda do carnaval da escola de samba da comunidade, Acadêmicos da Rocinha. Todos com o dia, horário e local marcados. São expressões que criam atualidade, referência geográfica, temporalidade e legitimam as imagens como verdades.

Paralelamente aos efeitos de real, observamos como as pessoas relatam suas histórias, percebem o mito ou a cultura em sua volta. Esse ponto de análise pode ser percebido também nos inúmeros grafites nas paredes da comunidade, como o registrado na fotografia D, publicada no Instagram no dia 9 de dezembro de 2017, por uma 


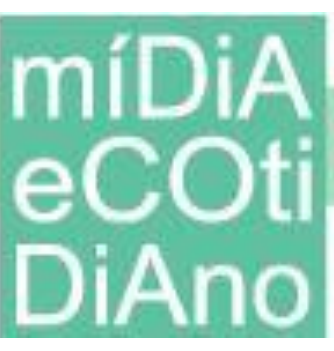

estrangeira que visitava a comunidade. O post faz referência a obra do artista plástico Carlos Esquivel, conhecido como Acme. Na cena, a Santa Ceia estilizada tem como personagem principal um Jesus negro, com cabelos no estilo black Power. Ele reparte uma pizza e abraça 12 pessoas de diferentes religiões e países, entre eles Brasil, Rússia, Polônia, Alemanha, Itália, Egito e Nigéria. A imagem tem um significado forte e moderno do momento histórico em que Jesus, ao lado dos 12 apóstolos, institui a eucaristia, o pão e o vinho, seu corpo, seu sangue. No contexto da Rocinha, a cena representa o amor, a paz, a união, a solidariedade entre os povos, o serviço ao próximo, a celebração da esperança, não importando a identidade ou raça. Na imagem, Jesus tem a cor de pele que representa mais da metade da população no país (54\%), negros ou pardos, segundo dados do IBGE. Nas favelas de todo o país, em 2014, os negros representavam $67 \%$ da população, segundo o Instituto Data Popular.

Figura 4 - grafites nas paredes da comunidade

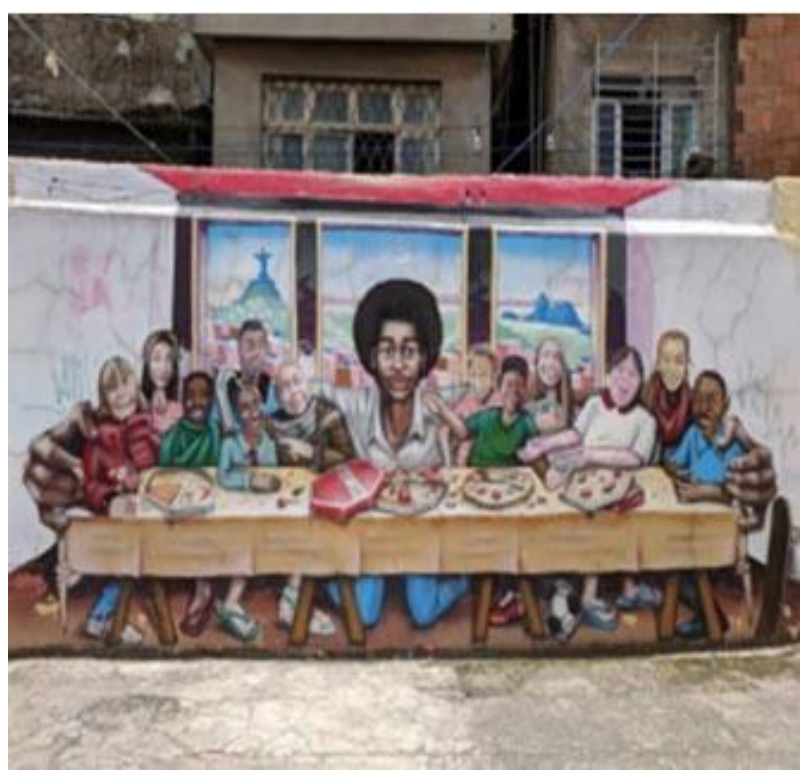

Fonte: Instagram.

Outro ponto importante na Narratologia proposta por Motta (2013) é observar o cotidiano, no qual recortamos também a categoria de representação do esporte na comunidade. Nesse quesito, aparecem 26 imagens (4,1\%). Musculação, judô, corrida, futebol e ioga foram as principais atividades físicas fotografadas. A categoria educação, 


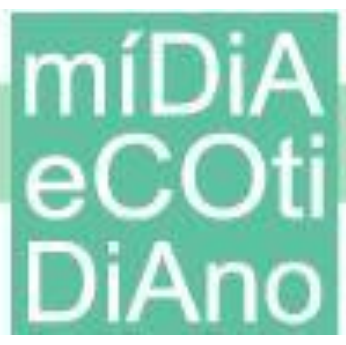

um dos estereótipos da favela, também nos chamou atenção. E ao contrário da ideia de que as pessoas nessas comunidades não têm nenhum acesso ao ensino, uma cena em destaque é a de um "amigo secreto" de livros, realizado pelo Pré-Vestibular Comunitário da Rocinha (PVCR), tendo como o símbolo a realização profissional por meio do diploma. A foto foi publicada em 9 de dezembro de 2017 por uma estudante da escola e reflete os dados da pesquisa do Data Favela de 2013, quando afirma que " $27 \%$ das pessoas das comunidades brasileiras leram ao menos um livro nos 12 meses anteriores e que sete em cada grupo de 10 moradores viam o estudo como alicerce para quem pretende subir na vida" (MEIRELLES E ATHAYDE, 2014, p. 116).

Completa esta observação uma foto de alunos participando do projeto Favela Phoenix. Criada em 2015 pelo britânico Jody King, que mora na Rocinha, a ação, financiada por doações, ensina inglês gratuitamente para os moradores da comunidade. Em 2018 a escola contava com 120 estudantes, sendo 80 adultos e 40 crianças.

Sobre a violência, do total de 630 imagens do nosso recorte, apenas $22(3,4 \%)$ fazem referência à violência. Entre elas, cinco mostram policiais armados, uma mostra dois policiais fazendo ronda e 11 fotos são do Rogério 157. No entanto, nenhuma delas foi publicada por moradores da Rocinha ou turista. As dos policiais armados foram postadas por perfis que cobrem ações policiais em todo o país e as do Rogério por fonte de notícias que divulgaram a sua prisão e usaram a hashtag \#Rocinha. Também foram os perfis de veículos de comunicação que publicaram as três imagens de policiais que fizeram selfie com o traficante preso e uma charge, criticando o episódio. A foto de uma jornalista de televisão fazendo a cobertura sobre a prisão de Rogério completa as imagens sobre o tema. Assim, no Instagram, durante o recorte da pesquisa, não há nenhuma imagem de outro criminoso ou qualquer tipo de violência envolvendo alguém da Rocinha.

\section{Conclusão}

O estudo sugere que as fotografias não são realidades puras, mas uma construção de significados sobre o real. São representações e interpretações de mundo em que membros de uma cultura usam a linguagem para produzir sentidos, que não são fixos, nem absolutos, mas que sua codificação e decodificação mudam de acordo com os mapas culturais e experiências de cada produtor e receptor. Neste sentido, compreender a 
fotografia como um corpo de práticas sociais é importante para entendermos o seu papel. As fotos nos contam histórias e dão visualidade a momentos diferentes da vida dos moradores da Rocinha.

Ao percorrermos o caminho de estudo proposto, vimos que, embora a violência e a guerra do tráfico existam e sejam problemas graves que devem ser resolvidos com políticas públicas efetivas e ação do governo, a representação da Rocinha no Instagram tende a fugir do estereótipo de criminalidade cristalizado pela mídia tradicional ao promover uma representação mais humanizada da favela, destacando seus moradores, as famílias, os amigos, a luta pelo crescimento econômico e cultural, a solidariedade, a educação e o modo de vida de seus habitantes. Um panorama ou prisma pouco conhecido de quem está do lado de fora, mas que é importante para legitimar a valorização de seus moradores que estão, cada vez mais, sufocados pela onda de violência que ocorre, não só na Rocinha, mas em todo o Rio de Janeiro, "a ponto de moradores de favelas verem-se instados a falsificar endereços para evitar discriminação quando procuram emprego" (MEIRELLES; ATHAYDE, 2014, p. 7).

No geral, essa diferença entre as fotos produzidas no Instagram e na grande mídia pode ser explicada pelas características e objetivos de cada meio de comunicação. O compromisso da narrativa jornalística é com o acontecimento. Assim, o jornalismo procura estabelecer estratégias de construção textual para estreitar laços entre o narrador e o fato reportado. Tal escolha é intencional e está marcada pelo efeito de sentido pretendido, em geral de denúncia de crimes, em tom sensacionalista. Escolhe-se o que será divulgado, os personagens, o ângulo da imagem, a luz, o clímax, a história a ser contada e o modo como ela será emoldurada. A visualização se dirige a um público cuja interpretação se baseia em significados dominantes sobre favela e violência no Rio de Janeiro.

No entanto, com as novas tecnologias como o Instagram, as imagens postadas se inserem em outra memória coletiva e são produzidas, na grande maioria, por pessoas que moram ou visitam a comunidade e que estão mais interessadas no cotidiano, nos detalhes, na alegria dos moradores e bons lugares para um registro. São memórias visuais de outras práticas sociais que, embora inseridas numa cultura de violência, representam uma alternância ao medo. 
Esta diferença de representações e desigualdade de poder confirma o que Martino ressalta ao estudar os conceitos de realidade mediada, proposta pelo pesquisador britânico Roger Silverstone, em 2007, onde as relações políticas e pessoais de hoje são vividas em boa parte nas telas digitais, onde o mundo que aparece é o mundo da aparência. No entanto, bem ou mal, cada vez mais, "é com essas aparências que vão se desenrolar as relações políticas e se vai compreender o outro" (MARTINO, 2015, p. 248). E como isso está sendo trabalhado com a Rocinha?

As diferentes fontes de imagens e representações sobre a Rocinha são importantes e devem ser observadas em conjunto para termos uma melhor noção da realidade da comunidade. Desta forma, o estudo sugere que as novas tecnologias da comunicação, como o Instagram, são alternativas para conhecermos melhor diferentes culturas e irmos além de representações dominantes que alimentam o imaginário. No caso em estudo, para o morador da Rocinha, é ainda um meio de conceder visibilidade à pluralidade representacional de uma comunidade que não deve ser vista de maneira unívoca e estigmatizada, como se ela não fizesse parte de um todo orgânico e mais amplo que é a cidade do Rio de Janeiro.

\section{Referências}

ADGHIRNI, Zélia Leal; MORAES, Francilaine. Instantaneidade e memória na pesquisa sobre jornalismo online. In: LAGO, Cláudia; BENETTI, Márcia. Metodologia de pesquisa em jornalismo. Petrópolis, RJ: Vozes, 2010.

BAUER, Martin; GASKELL, George. Pesquisa qualitativa com texto, imagem e som. Petrópolis, RJ: Vozes, 2002.

BIANCHI; Paula. Historiador relata 'rotina de guerra' na Rocinha: 'nossos direitos estão suspensos e a cidade aprova'. UOL, Rio de Janeiro, 6 fev. 2018. Disponível em: <http://bit.ly/30cscn3>. Acesso em: 25 jan. 2018.

BOURDIEU, Pierre. Outline of a theory of practice. Cambridge: Cambridge University Press, 1977.

BRESSANE, Ronaldo. Tudo por um like. Galileu, Rio de Janeiro, maio 2014. Disponível em; <https://glo.bo/2N9nZwO>. Acesso em: 22 jan. 2018.

BURKE, Peter Burke. Testemunha Ocular: história e imagem. São Paulo, SP: Unesp, 2017. 


\section{míDiA

CASTELLS, Manuel. Communication Power. Cambridge, MA: MIT, 2010.

COM 50 MILHÕES de usuários, Brasil é segundo no ranking do Instagram. Folha de S. Paulo, São Paulo, 28 out. 2017. Disponível em <http://bit.ly/2YZ0E8a>. Acesso em: 11 jan. 2018.

EAGLETON, Terry. A ideia de Cultura. São Paulo: Unesp, 2005.

ENTRE as 9 comunidades com mais tiroteios no Rio, 4 têm UPPs; Cidade de Deus lidera. G1, Rio de Janeiro, 1 fev. 2018. Em <https://glo.bo/30d6ejV>. Acesso em: 2 fev. 2018.

HALL, Stuart (org.). Representation: cultural representations and signifying practices. London: Sage Open University, 2009.

HALLBWACHS, Michel. A Memória Coletiva. São Paulo: Vértice/Revista dos Tribunais, 1990.

HOUAISS, Antônio. Pequeno Dicionário Houaiss da Língua Portuguesa. São Paulo: Moderna, 2015.

IBGE. Censo demográfico 2010. Aglomerados subnormais: primeiros resultados. Rio de Janeiro: IBGE, 2011.

INSTAGRAM tem 800 milhões de usuários ativos por mês e 500 milhões por dia. G1, 25 set. 2017. Disponível em <https://glo.bo/2KUhbQS>. Acesso em: 12 jan. 2018.

KELLNER, Douglas. A cultura da mídia. Bauru, SP: EDUCS, 2001.

MARTINO, Luís Mauro. Teoria das mídias digitais: linguagens, ambientes e redes. Petrópolis, RJ: Vozes, 2015.

MEIRELLES, Renato; ATHAYDE, Celso. Um país chamado favela: a maior pesquisa já feita sobre favela brasileira. São Paulo: Gente, 2014.

MIANI, Rozinaldo Antonio. Charge Editorial: Iconografia e pesquisa em história. Domínios da Imagem, Londrina, v. 8, n. 16, p. 133-145, jun./dez. 2014. Disponível em: <http://bit.ly/31K5EdW>. Acesso em: 20 jan. 2018.

MIRZOEFF, Nicholas. An Introduction to Visual Culture. Londres: Routledge, 2010. MOTA, Célia Ladeira. A narrativa semiótica da imagem. In: MOTA, Célia Ladeira; MOTTA, Luiz Gonzaga; CUNHA, Maria Jandyra. (Orgs.) Narrativas Midiáticas, Florianópolis: Insular, 2012. 
MOTA, Célia Ladeira. Hermenêutica e as faces da linguagem. In: PORTO, Sérgio Dayrell; MOTA, Célia Ladeira. (Orgs.) Hermenêutica e análise dos discursos em jornalismo. Florianópolis: Insular, 2017.

MOTTA, Luiz Gonzaga. Análise crítica da narrativa. Brasília: Universidade de Brasília, 2013.

RECUERO, R. (2012). A conversação em rede: comunicação mediada pelo computador e redes sociais na Internet. Porto Alegre: Sulinas, 2012.

WILLIAMS, Raymond. Cultura. Rio de Janeiro: Paz e Terra, 2011.

WOODWARD, Katherine. 'Identidade e diferença: uma introdução teórica e conceitual'. In: SILVA, Tomaz Tadeu. (Org.) Identidade e diferença: a perspectiva dos estudos culturais. Petrópolis: Vozes, 2012. 